\title{
H. L. A. HART
}

\author{
Matt KRAMER
}

Herbert Lionel Adolphus Hart (1907-1992) was the foremost legal philosopher and one of the foremost political philosophers of the twentieth century. Born to a Jewish family in Yorkshire, England, Hart pursued his undergraduate education at Oxford and went on to qualify as a barrister. After practicing law for several years, he worked for the British intelligence service MI5 during the Second World War. When the War had ended, he returned to Oxford to take up a Fellowship in Philosophy at New College. He subsequently became Professor of Jurisprudence at Oxford (and a Fellow of University College), and still later became Principal of Brasenose College. During the closing years of his career as an active scholar, he devoted much of his time to editing and interpreting the works of Jeremy Bentham. Many former students of his, including Ronald Dworkin, Joseph Raz, John Finnis, Neil MacCormick, Herbert Morris, and Wilfrid Waluchow, have been among the most prominent legal philosophers of the next generation.

Hart is best known for his contributions to legal philosophy generally and to legal positivism specifically. While acknowledging his intellectual debts to his great positivist predecessors Bentham and John Austin, he severely criticized their theories for obscuring the normative dimension of law (that is, law's orientation toward what ought to be). At the same time, he emphasized that the normativity of law is not necessarily moral; throughout his jurisprudential 
work, he maintained a legal-positivist insistence on the separability of law and morality. In his classic 1961 book The Concept of Law, and in a number of essays written approximately contemporaneously, he presented a hugely influential account of the ways in which different types of norms combine to form the structure of a legal system. He laid particular stress on what he designated as the "Rule of Recognition" - namely, the array of normative presuppositions that underlie the behavior of legal officials (especially judges and administrators) as they ascertain the existence and contents of the laws in their system of governance. Under the prevailing Rule of Recognition in a jurisdiction, legal officials are both authorized and obligated to follow specific criteria in determining which norms possess the status of laws. Those criteria typically fix upon familiar sources of law such as legislative enactments or adjudicative rulings or administrative regulations or constitutional provisions.

The Rule of Recognition is one of three main types of secondary norms, which Hart distinguished from the primary norms of any legal system. Whereas the primary norms are duty-imposing and liberty-conferring laws that are all directly applicable to the conduct of ordinary members of the public, many of the secondary norms of a legal system are juristic standards that are directly addressed to the officials of the system only. The category of secondary norms comprises not only the Rule of Recognition, but also rules of change (which confer private powers or public powers to alter the existing legal norms) and rules of adjudication (which empower and obligate certain officials to deal with actual or alleged violations of the prevailing laws). The Concept of Law presents the combination of primary laws and secondary laws as the central structural feature of every legal system.

Hart famously distinguished between certain attitudes or perspectives that can be adopted in relation to any pattern of norm-guided behavior such as the operations of a system of legal governance. A theorist who adopts an extreme ex- 
ternal viewpoint will regard such behavior as an array of sheer regularities akin to the movements of cloud-formation or of atmospheric pressure. Such a theorist makes no effort to see people's actions in the ways in which they are seen by the people themselves. Much more sensible is a moderate external perspective. A theorist who takes up such a stance is of course attentive to the observable regularities that are the preoccupation of the extreme external perspective, but he focuses centrally as well on people's attitudes and beliefs. In particular, he attributes normative attitudes and beliefs to people whose behavior indicates that they accept certain standards as binding upon them. Though he does not regard himself as bound by those standards - at least insofar as he occupies an external perspective - he highlights the attitude of commitment that is felt by the people whose conduct he is investigating.

Both of these versions of the external perspective differ from the internal point of view, which is the stance of an engaged participant in a practice. Somebody who occupies the internal point of view is seeking to sustain the workings of an institution or a practice, for moral reasons or for prudential reasons. Such a person takes a censorious attitude toward violations of the norms of the institution or practice -including her own violations - and she cites the norms in justification of her criticism. She demands compliance with the norms as such, and she acknowledges the warrantedness of any pertinent demands and criticisms that are directed at her with reference to those norms by her fellow participants. The attitude of endorsement is what distinguishes this perspective from either of the external perspectives delineated above. To embrace the internal point of view is to forsake disengagement by committing oneself to upholding the norms of some practice or institution.

For Hart, the characteristic stance of the officials who run a legal-governmental system is the internal perspective. Indeed, he maintained that the adoption of that perspective by most such officials on most occasions is a necessary 
condition for the existence of any such system (or, at least, for the existence of any straightforward instance of such a system). By contrast, the characteristic stance of a jurisprudential theorist is the moderate external point of view. Some legal sociologists might favor the extreme external perspective, but - as Hart argued at several junctures in The Concept of Law- any such approach is far too impoverished for jurisprudential purposes. To attain a satisfactory philosophical understanding of the operations of any legal system, a theorist must apprehend the normativity of those operations.

Though Hart's rejection of the extreme external perspective has been followed by virtually every philosopher of law, his embrace of the moderate external perspective for jurisprudential analysis has been challenged by Ronald Dworkin for the past four decades. Dworkin contends that an illuminating account of law must be elaborated from the viewpoint of a committed participant. He holds that any such account has to be constructive in the sense of being favorably disposed toward the phenomenon which it expounds; it has to seek to portray that phenomenon in the most appealing light. Although this insistence by Dworkin is an element of his longstanding opposition to legal positivism's affirmation of the separability of law and morality, many opponents of positivism distance themselves from his stand on this point. Quite a few of those opponents, such as Finnis, join Hart in taking up a moderate external point of view when they seek to expound the nature of law.

Still, although Finnis aligns himself with Hart against Dworkin on the methodological matter just mentioned, his understanding of the ambitions of jurisprudential enquiry differs significantly from Hart's. Finnis maintains that the central role of such enquiry is to highlight the morally valuable functions that are performed by the operations of legal systems. He therefore contends that the moderate external perspective of the jurisprudential theorist should be oriented toward legal officials whose aims in their activities as 
officials are morally benign. By contrast, Hart took the central role of jurisprudential enquiry to be theoretical-explanatory. He sought to provide a philosophical explication of the concept of law which would comprehend all clear-cut legal systems and which could potentially be extended to cover all other legal systems as well. He wanted to leave open the nature of the aims of the officials in particular legal systems, instead of focusing centrally on officials whose motivations are benign. He recognized of course that the officials in many standard legal systems do act on the basis of morally salutary considerations, but he endeavored to come up with an account of law that would cover also the standard legal systems in which the officials collectively pursue malevolently self-interested aims. Such an account can highlight the features of the rule of law that are common to the benevolent regimes and the malevolent regimes, and can explore how those features are promotive of benign ends and many malign ends. Hart's theoretical-explanatory project was thus markedly different from Finnis's morally fraught approach to jurisprudential theorizing.

In his opposition to the positions taken by Dworkin and Finnis, and in his opposition to the positions taken by numerous other natural-law theorists such as Lon Fuller, Hart upheld legal positivism's insistence on the separability of law and morality. Though some subsequent legal positivists have spoken of a "separability thesis," any such language is highly misleading. Legal positivists differ among themselves concerning what the separability of law and morality involves, and the debates between sundry positivists and natural-law theorists have been multifarious. The socalled separability thesis is in fact a congeries of theses. Hart patently recognized as much, for he disentangled a number of respects in which law and morality have been perceived as necessarily connected. His initial concern, which he shared with Austin, was to deny that a norm must satisfy some threshold test of moral legitimacy if it is to count as a genuine law. However, he then broadened the 
scope of his reflections as he pondered a number of other efforts by natural-law theorists to postulate necessary connections between law and morality. For example, he considered and rejected the thesis that every legal mandate simply by dint of its status as such a mandate imposes on every one of its addressees a pro-tanto moral obligation of compliance. One thing that has become apparent as a result of Hart's jousting with diverse natural-law theorists is that some distinct conceptions or dimensions of morality are varyingly in play when the separability of law and morality is under discussion. The multiplicity of those conceptions or dimensions is partly what accounts for the numerousness of the disputes between legal positivists and their foes.

Although The Concept of Law is principally a work of legal philosophy, it contains some important discussions of topics in political and moral philosophy. Hart's first major contribution to political philosophy occurred in his 1955 essay "Are There Any Natural Rights?" In that essay, Hart briefly introduced a theory of political obligation that has come to be known as the "principle of fair play" (a principle later elaborated by his friend John Rawls). That is, he contended that anyone who benefits greatly from the presence of some institution is morally required to bear a commensurate share of the burdens of sustaining that institution's existence. Although the principle of fair play has often come under attack in the decades since Hart fleetingly propounded it, it continues to be espoused by some presentday political philosophers.

On the basis of some remarks made en passant by Hart in The Concept of Law, the principle of fair play has also been developed by quite a few philosophers of criminal law into a version of the retributivist justification for punishment. Their claim is that somebody who commits a crime has benefited from the law-abidance of others without fully bearing his own share of the burdens of law-abidance. Such a wrongdoer should be subjected to punishment in 
order to deprive him of his unjust gain. Proponents of this version of retributivism have sometimes encountered difficulty in specifying credibly the nature of the gain that is undergone by a criminal. However, the plausibility of the theory can be salvaged if the gain is understood as the self-indulgence of a malefactor that consists in his use of his body and certain external things in forbidden ways. The extent of that self-indulgence in any particular case is determined not by what the malefactor would be willing to pay to commit his crime with impunity, but by what the community would demand in return for allowing his commission of it.

Hart himself argued in his Punishment and Responsibility for a deterrence-oriented account of punishment, combined with retributivist side-constraints. That is, he maintained that the central purpose of punishment is the reduction of crime through deterrence; the aim of crime-reduction is what justifies the use of sanctions and is what determines the sanctions' appropriate levels of severity. Retributivism's insistence on guilt as a necessary condition for the legitimacy of the imposition of any punitive measures is pertinent not when we are addressing the purpose of such measures, but instead when we are pinning down the circumstances in which they can properly be imposed. Retributivism with its emphasis on moral responsibility circumscribes the range of situations in which someone can legitimately be punished, as it disallows the use of sanctions against anybody who has not committed the crimes for which the sanctions are levied. Supplemented in this fashion with retributivistic side-constraints, a deterrence-oriented justification of punishment will have shed some of its most dismaying implications.

Hart's most sustained entry into political disputation occurred in 1963, with the publication of his Law, Liberty, and Morality. Hart wrote in the liberal tradition of John Stuart Mill by arguing that fornication and homosexual intercourse between consenting adults should not be legally proscribed. Invoking and defending Mill's "harm principle," 
which maintains that no mode of conduct can legitimately be outlawed unless the conduct causes nontrivial harm to somebody other than the person who engages in it, Hart submitted that consensual intercourse between adult homosexuals does not cause any detriment that would suffice to satisfy the harm principle. In particular, the mere fact that unorthodox sexual practices cause offense to some people who are aware of their occurrence does not constitute harm of any kind that would render legitimate the prohibition of those practices. Hence, although Hart's position in Law, Liberty, and Morality was broadly utilitarian with a focus on the misery caused by legal prohibitions that bar people from behavior which offends some other people but which is otherwise harmless, his utilitarianism was not thoroughgoing. As a liberal, Hart was not prepared to treat the disutility of mere offense as a consideration to be weighed against countervailing considerations in his assessment of the legitimacy of various legal-governmental regulations.

In several writings included in his Essays on Bentham and Essays in Jurisprudence and Philosophy, Hart made noteworthy contributions to debates over the nature of rights and justice. He joined Rawls and Robert Nozick in rejecting utilitarian rationales for sacrificing the vital interests of some individuals in furtherance of the interests of others, but he likewise assailed the extreme individualism of Nozick's libertarian principles of justice. Generally sympathetic to Rawls's ideas, Hart nonetheless challenged Rawls's remarks about the overriding priority of liberty. (Among other things, he queried Rawls's unexplained shift from speaking about the priority of liberty to speaking about the priority of liberties). What Hart impugned was not really the priority of certain liberties but instead the claim by Rawls to have derived that priority from a situation of pure rational choice - the "Original Position" - in which each choosing agent seeks to promote his or her own interests optimally. Rather, Hart declared, the only tenable basis 
for Rawls's prioritization of certain liberties is a liberal ideal of human personality.

Hart further exhibited his liberal allegiances in his analysis of the nature of rights. He contended that the holding of a legal right by any person $P$ always involves the vesting of $P$ with legal powers to waive or demand the enforcement of the legal duty that is correlated with the right. Hart adopted this analysis precisely because he believed that no alternative conception of right-holding would capture the role of rights in enabling individual self-determination. His account of rights, like his other political stances, was grounded on liberal values.

One additional major achievement by Hart that is well worth noting here is his analysis of causation in the magisterial volume Causation in the Law which he co-authored with Tony Honoré. Working with an abundance of cases in tort law and criminal law from several jurisdictions, Hart and Honore sought to distill the principles which explicitly or implicitly underlie the causal judgments that are reached in such cases. Their central analysis of causation, whereby an event or a fact is causative if and only if it is a member of a set of conditions that are minimally sufficient for some result, has influenced not only philosophers of law but also moral philosophers and metaphysicians and philosophers of action (A set of facts or events is minimally sufficient for some result if and only if it is sufficient for that result and it contains no redundant elements -in other words, no elements that are unnecessary for its sufficiency). Hart and Honoré went on to adduce some considerations that sway the decisions of courts in singling out certain factors as legally decisive causes. Their key point was that the factor singled out as the legally responsible cause in any particular case is something that has disrupted the normally foreseeable course of events. Such a disruption occurs if someone has acted voluntarily with the intention of bringing about a detrimental consequence that is at issue, or if some action or event has taken place in a context 
where the action or event is abnormal. Unlike the criterion for causal efficacy recounted above, these considerations for deeming a cause to be legally decisive are overtly evaluative. Hart and Honoré made clear in their exposition that each such consideration is indeed broadly ethical. In their view, legal responsibility —within the jurisdictions which they studied- is always implicitly or explicitly a matter of political morality.

\section{REFERENCES}

HART, H. L. A. 1961, The Concept of Law, Oxford, Clarendon Press.

- 1963, Law, Liberty, and Morality, Oxford, Oxford University Press.

- 1968, Punishment and Responsibility, Oxford, Clarendon Press.

- 1982, Essays on Bentham, Oxford, Clarendon Press.

- 1983, Essays in Jurisprudence and Philosophy, Oxford, Clarendon Press.

- and Honoré, A. M. 1958, Causation in the Law, Oxford, Clarendon Press.

\section{SUGGESTED READINGS}

ADLER, Matthew and HimmA, Kenneth (eds.) 2009, The Rule of Recognition and the U.S. Constitution, Oxford, Oxford University Press.

CANE, Peter (ed.) 2010, The Hart-Fuller Debate in the Twenty-First Century, Oxford, Hart Publishing.

Coleman, Jules (ed.) 2001, Hart's Postscript, Oxford, Oxford University Press.

DWORKIN, Ronald 1978, Taking Rights Seriously, Cambridge, MA, Harvard University Press. 
FINNIS, John 1980, Natural Law and Natural Rights, Oxford, Oxford University Press.

FUller, Lon 1965, The Morality of Law, New Haven, CT, Yale University Press.

GAVISON, Ruth (ed.) 1987, Issues in Contemporary Legal Philosophy: The Influence of H. L. A. Hart, Oxford, Oxford University Press.

Kramer, Matthew 1999, In Defense of Legal Positivism, Oxford, Oxford University Press.

- et al. (eds.) 2008, The Legacy of H. L. A. Hart, Oxford, Oxford University Press.

LACEY, Nicola 2004, A Life of H. L. A. Hart. Oxford, Oxford University Press.

MACCORMiCK, Neil 1981, H. L. A. Hart. Stanford, CA, Stanford University Press.

RAZ, Joseph 2009, The Authority of Law, 2nd. ed., Oxford, Oxford University Press.

SHAPIRO, Scott 2011, Legality, Cambridge, MA, Harvard University Press.

WAluchow, W. J. 1994, Inclusive Legal Positivism, Oxford, Oxford University Press. 